\title{
短報
}

\section{瀬戸内海西部における市場での 八モの魚体測定方法}

亘 真吾, ${ }^{2 *}$ 村田 実, ${ }^{2}$ 馬場俊典, ${ }^{2}$ 樋下雄一, ${ }^{3}$ 三代和樹, 4 尾田成幸, 5 石谷 誠 6

(2013 年 7 月 2 日受付, 2013 年 9 月 8 日受理) 1独水産総合研究センター瀬戸内海区水産研究所,

${ }^{2}$ 山口県水産研究センター,

3 大分県農林水産研究指導センター水産研究部,

4 大分県東部振興局,

5福岡県水産海洋技術センター,

6 福岡県農林水産部

A method of measuring the body size of daggertooth pike-conger Muraenesox cinereus at fish markets in the western Seto Inland Sea, Japan

SHINGO WATARI, ${ }^{1 *}$ MinORU MURATA, ${ }^{2}$ TOSHINORI BABA, ${ }^{2}$ YUICHI HINOSHITA, ${ }^{3}$ KAZUKi MISHIRO, ${ }^{4}$ SHIGEYUKI ODA ${ }^{5}$ AND MAKOTO ISHITANI ${ }^{6}$

${ }^{1}$ National Research Institute of Fisheries and Environment of Inland Sea, Fisheries Research Agency, Hatsukaichi, Hiroshima 739-0452, ${ }^{2}$ Yamaguchi Prefectural Fisheries Research Center, Aiofutajima, Yamaguchi 754-0893, ${ }^{3}$ Fisheries Research Division, Oita Prefectural Agriculture, Forestry and Fisheries Research Center, Usa, Oita 8790608, ${ }^{4}$ Oita Prefecture Eastern Region Bureau, Kunisaki, Oita 873-0504, ${ }^{5}$ Fukuoka Fisheries and Marine Technology Research Center, Buzen, Fukuoka 828-0022, ${ }^{6}$ Department of Agriculture, Forestry and Fisheries, Fukuoka Prefectural Government, Hakata, Fukuoka 812-8577, Japan

キーワード : 市場調査, 魚体測定, 瀬戸内海, 全長, 体 重, 八乇

瀬戸内海西部の山口県, 福岡県, 大分県, 愛媛県に囲 まれる安芸灘, 伊予灘, 周防灘では, 多くの魚種で漁獲 量が減少傾向にあるなか, 八モ Muraenesox cinereus の 年間漁獲量は, 1970 年代の平均 45 トンから，2000 年 以降は平均 800 トン以上へと大幅に増加している。 八モは関西圏に打いて高級食材として取扱われてお り, ${ }^{3)}$ 山口県では山口県漁協などが中心になり, 関西圈 へ共同出荷の取り組みがなされている。高水準の漁獲が 今後も継続するか否かは, 漁業者や加工業者の重要な関 心事であり，資源調査体制の構築と資源管理の推進が望
まれている。市場における漁獲物の体長や体重の計測 は, 資源の持続的利用を図る上で基礎的情報として, 多 くの魚種で定期的に実施されている。礼しかし，八モ は, 活魚で出荷される場合, 小型のバケツやコンテナに 湾曲して收められているため，定規を用い簡単に全長を 計測することが出来ない。仮に全長の計測を試みても， 獰猛な八モに測定中に噛みつかれる危険があり，魚体測 定は困難を極める。また, 活締めの場合は, 漁業者が出 荷前に後頭部を切断するため，全長を正確に測定するこ とが出来ない (Fig. 1a, b)。このため, 高水準の漁獲が 続くハモであるが，これまで，市場調査で全長組成を把 握するためのサイズ計測が十分に実施されてこなかっ た。そこで, 活魚, 活締めそれぞれで, 安全かつ正確に 測定可能な部位を検討するとともに，全長，体重への換


Fig. 1 Handling of daggertooth pike-conger at fish markets of the western Seto Inland Sea area. (a) Live fish, (b) spiking, (c) putting many individuals in one box.

* Tel : 81-829-55-0666. Fax : 81-829-54-1216. Email : swatari@affrc.go.jp 




Fig. 2 Measurement points of total length, predorsal length and length of lower jaw. The dotted-line triangle shows the cutting part for spiking.

Table 1 Parameter estimates, coefficient of determination $\left(R^{2}\right)$ and Akaike's information criterion (AIC) values of the allometric equation between total length $(T L, \mathrm{~mm})$ and body length $(B L, \mathrm{~mm})$, and between body weight $(W, \mathrm{~g})$ and body length

\begin{tabular}{|c|c|c|c|c|c|}
\hline$B L$ & Sex & $\left(T L=\stackrel{\alpha}{\alpha} B L^{\beta}\right)$ & $\beta$ & $R^{2}$ & AIC \\
\hline \multirow{3}{*}{ Predorsal length } & Unsexed & $16.34(0.34)$ & $0.82(0.004)$ & 0.94 & 22,085 \\
\hline & Male & $18.96(0.91)$ & $0.78(0.011)$ & 0.88 & \multirow{2}{*}{22,007} \\
\hline & Female & $17.73(0.47)$ & $0.80(0.006)$ & 0.93 & \\
\hline \multirow{3}{*}{ Length of lower jaw } & Unsexed & $36.79(0.73)$ & $0.76(0.005)$ & 0.91 & 22,881 \\
\hline & Male & $45.71(2.01)$ & $0.70(0.012)$ & 0.84 & \multirow{2}{*}{22,803} \\
\hline & Female & $38.41(0.98)$ & $0.75(0.006)$ & 0.91 & \\
\hline$B L$ & Sex & $\left(W=\stackrel{a}{a} B L^{b}\right)$ & $b$ & $R^{2}$ & AIC \\
\hline \multirow{3}{*}{ Predorsal length } & Unsexed & $0.0023(0.000198)$ & $2.65(0.018)$ & 0.92 & 27,390 \\
\hline & Male & $0.0042(0.000984)$ & $2.52(0.051)$ & 0.86 & \multirow{2}{*}{27,362} \\
\hline & Female & $0.0026(0.000266)$ & $2.63(0.021)$ & 0.92 & \\
\hline \multirow{3}{*}{ Length of lower jaw } & Unsexed & $0.030(0.00262)$ & $2.49(0.021)$ & 0.89 & 28,267 \\
\hline & Male & $0.044(0.01067)$ & $2.38(0.062)$ & 0.82 & \multirow{2}{*}{28,246} \\
\hline & Female & $0.036(0.00366)$ & $2.45(0.025)$ & 0.88 & \\
\hline$T L$ & & $\left(W=a T L^{b}\right)$ & & & \\
\hline \multirow{3}{*}{ Total length } & Unsexed & $3.36 \times 10^{-7}\left(3.43 \times 10^{-8}\right)$ & $3.21(0.015)$ & 0.96 & 25,941 \\
\hline & Male & $7.70 \times 10^{-7}\left(2.22 \times 10^{-7}\right)$ & $3.08(0.044)$ & 0.93 & \multirow{2}{*}{25,935} \\
\hline & Female & $2.96 \times 10^{-7}\left(3.60 \times 10^{-8}\right)$ & $3.23(0.018)$ & 0.96 & \\
\hline
\end{tabular}

Values in parentheses show the standard error of the parameters.

算式を推定し，八モの測定方法を確立する必要がある。

活魚の場合，基本的に背面を上にして遊泳しているた め, 吻端から背鰭起部は容易に認識できるうえ, 遊泳に よる湾曲も少なく直線で計測可能な部位である。また, 首を切断された活締めの場合，下顎は切断箇所の影響が なく, 認識が容易で長さを計測できる部位と考えられる (Fig. 2)。これらの部位加全長 $T L(\mathrm{~mm})$ や体重 $W(\mathrm{~g})$ を推定することの妥当性を検証するため, 2010 年 11 月 〜 2012 年 9 月に, 瀬戸内海西部で小型底曳網漁船で捕 獲したハモの雄 827 尾（TL: 307 828 mm）, 雌 1,443 尾（TL: $270 \sim 1,253 \mathrm{~mm}$ ）をもちい，各個体の $T L$ を 定規で $1 \mathrm{~mm}$ 単位, 背鰖前長（吻端から背鰖起部までの 長さ）, 5) 下顎長（下顎の先端からその最後端までの長 さ) 6) を電子ノギスで $0.01 \mathrm{~mm}$ 単位， $W$ を電子天秤を用 い $1 \mathrm{~g}$ 単位で計測した。生殖腺を摘出し, 実体顕微鏡ま
たは目視で雌雄を判定した。計測部位（背鯺前長または 下顎長） $B L$ から $T L, W$ への換算式として，アロメト リ一式 $T L=\alpha B L^{\beta}, W=a B L^{b}$ を使用した。また， $T L$ か ら $W$ の関係式 $W=a T L^{b}$ も併せて推定した。

$B L$ と $T L, B L$ と $W, T L$ と $W$ の関係のアロメトリー 式のパラメータの点推定值と標準誤差を Table 1 に示す。 $B L$ と $T L$ の間の決定係数はいずれも 0.84 以上で，モ デル式はデータをよく説明した。また, 全長, 背鰔前 長，下顎長のいずれの部位も，Wとの間に正の相関が 久られた。雌雄込反と雌雄別の関係式の赤池情報量規準 (AIC) の值を比較したところ，いずれの部位と $T L, W$ の関係式においても雌雄別に推定した換算式の方が, 当 てはまりが良いと判断された。なお，予備的に直線関係 の回帰式も推定し AIC を比較したが，アロメトリー式 のあてはまりが良かった。 
背䰹前長, 下顎長から TLを推定するアロメトリー式 はいずれも，係数 $\beta$ が 1 未満で上に凸の曲線となる。

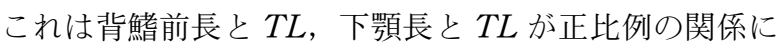
ないことを示す。換算式はいずれの部位も, 雌雄別に推 定した方が当てはまりがよかった。産卵期の抱卵個体な ど外見から雌と判断できるケースもあるが，通常の調查 では, 雌雄込みの換算式を使用することになる。雌雄別 の換算式で得られる全長に対する, 雌雄込反の換算式で 得られる全長の比率は, 漁獲対象サイズである全長 600 $\mathrm{mm}$ 以上では，背鯺前長からの換算で $-2 \% \sim+1 \%$, 下顎長からの換算で $-3 \%$ + 1\% であった。同様に体 重では, 背鯺前長からの換算で $-6 \% \sim+2 \%$, 下顎長 からの換算で $-6 \%$ +3\%であった。このうち, 雌で は $\pm 2 \%$ の範囲で収まり, 雄の大型個体になるにつれ 誤差が拡大した。これは雄より雌の方が大きく成長する ため, 雌の大型個体の影響を受けるためと考えられる。 雄については精度が落ちるが，その誤差の程度は少な く, かつ, 外見での雌雄の判定は困難なことから, 便宜 的に雌雄込みの換算式を使用するのが妥当と考えられる。

市場で水揚物の全長や体長を直接計測する以外の方法 として, 写真画像解析による測定 ${ }^{7,8)}$ が考案されてい る。今井ら ${ }^{7)}$ が紹介しているムシガレイの例では, 吻端 から尾䰹後端までの 2 点間の直線距離を画像解析ソフ トウェアで計測し，全長を推定しているが，魚体が湾曲 している場合には，体軸上を通る $2 \sim 5$ 本に分割した測 定線を合計し全長を推定している。活締めの八モの場合, Fig. 1a に示すように，ほとんどの個体で湾曲して容器 に収められて抢り, 写真画像から全長を推定するには, 5 本または，それ以上の測定線を足しあわせ，全長に換 算する必要がある。1つの箱に納められている八モが少 ない場合には, 写真画像から下顎長や背鰭前長を計測す ることで $T L や W の$ 推定が可能である。しかし, 盛漁 期には, 1 つ箱に一部活魚の八モが大量に納められ, 頭部が他の八モの下に隠れる場合もあり, 写真撮影では 十分に計測部位を把握できない (Fig. 1c)。八モの細長 い体形や, 瀬戸内海西部での取扱形態を考慮すると, 下 顎長や背鰭前長を直接計測し, $T L$ や $W$ に換算するの が，簡便かつ確実に情報を得られる方法と考えられる。

実際の市場での活魚の測定においては, 単に定規を頭 部に当てるのではなく, 直角定規など L 字型の計測器 具を用いることで，八モの噛みつきによる負傷の危険性 を減少させることが可能である。市場によっては, 活魚
のハモが小型のバケツやコンテナではなく, 大型水槽に 収容され遊泳しており, 背鰭前長などを直接計測するこ とが困難な場合がある。このような場合でも，水揚まで の取扱いの過程で死亡する個体が一部存在する。サイズ 別死亡率について別途検証する必要はあるが，死亡する 個体の全長組成を利用し，大型水槽内に打的壬の全 長組成を推定することは可能と考えられる。また, 下顎 長の測定は, 市場調查のみならず, サワラ調査で行われ ているように, ${ }^{9)}$ 通常廃棄物として捨てられる頭部を, 水産物加工場から調達することで, 大量かつ容易に水揚 物の全長組成を把握することが可能と考えられる。本研 究で得られた換算式と, 漁業現場の実態を考慮した工夫 を加味することで, 従来困難であった八モのサイズ組成 の情報が得られる。また, 他海域の八モについても本研 究で示した体サイズの計測方法が, 八モの資源調查の推 進に役立つものと考えられる。

\section{謝辞}

ハモのサンプル収集にご協力頂いた，大分県漁業協同 組合の岡部藤岡氏, 渡辺英敏氏, 寺本 操氏に深謝いた します。本論文の作成にあたり有益な助言を頂いた，日 本海区水産研究所の銭谷 弘博士に深く感謝いたしま す。本研究の一部は, 「水産庁我が国周辺水域資源評価 等推進委託事業」により実施しました。

\section{文献}

1）瀬戸内海漁業灘別漁獲統計累年表（昭和 $27 \sim 59$ 年）。 日 本水産資源保護協会, 東京. 1986.

2）平成 $12 \sim 17$ 年瀬戸内海区及び太平洋南区における漁業動 向. 中国四国農政局統計部，岡山. 2002 2007.

3）多紀保彦, 武田正倫, 近江 卓.「食材魚介大百科第一 巻 エビ・カ二類 + 魚類」平凡社, 東京. 1999 .

4) 平成 23 年度我が国周辺水域の漁業資源評価. 水産庁, 水 産総合研究センター, 東京. 2012 .

5）山田梅芳, 時村宗春, 堀川博史, 中坊徹次.「東シナ海・ 黄海の魚類誌」東海大学出版会, 秦野. 2007.

6）高井 徹. 日本産重要ウナギ目魚類の形態, 生態および増 殖に関する研究. 水産講習所研究報告 1959; 8: 209-555.

7）今井千文, 宮崎義信, 時村宗春, 山本圭介. 写真画像解析 による体長測定法の開発 : ムシガレイ漁獲物の銘柄別全長 組成推定への応用. 水産海洋研究 2005; 69: 18-26.

8）内山 勇. 写真画像によるベニズワイガニ漁獲物のサイズ 測定方法. 富山県農林水産総合技術センター水産研究所研 究報告 $2009 ; 1$ : 1-6.

9）千葉眞佐光, 加藤利弘, 河野芳巳, 関 信一郎. 愛媛県伊 予灘におけるサワラの漁況予測の可能性. 水産海洋研究 2010; 74: 81-87. 